\title{
Apresentação: dossiê Os Sertões
}

1 o centenário de Os Sertôes de Euclides da Cunha, em 2002, o teatro Oficina de São Paulo dedicou todas as suas energias a processar este livro, ao mesmo tempo totem e tabu da cultura brasileira. Não foi a primeira vez que o Oficina debruçou-se sobre as páginas densas e áridas do livro. Como aponta Maria Thereza Vargas, em um dos ensaios deste dossiê, já em 1969, em A Selva das Cidades, o grupo liderado por José Celso Martinez Correa anunciava a disposição de enfrentar o desafio de Os Sertôes. Não foi possível, na época, concretizar o projeto, mas veio Gracias Señor, verdadeira pedra de fundação da Uzyna Uzona e de todos os espetáculos que gerou. Nestes últimos 30 anos, muitas foram as vezes que as palavras de Euclides e a saga de Conselheiro voltaram a cruzar-se com os passos de José Celso e os caminhos do Oficina, sem nunca consumarse uma montagem integral da obra.

Em 2000, premido pelas circunstâncias de um embate do tipo David contra Golias (a ameaça de um shopping center incorporado por um poderoso grupo econômico enlaçar a estreita caixa do teatro Oficina), José Celso decidiu retomar Os Sertôes e iniciou um paciente processo de leitura detida, em que, ao lado do jovem coletivo que hoje integra o grupo, ia-se lendo cuidadosamente e parando-se a cada vez que uma palavra estranha surgia para consultar o dicionário. Como Os Sertôes é um livro pródigo em palavras pouco conhecidas, a leitura era truncada a cada frase, e vários meses foram necessários para que ela se cumprisse.

Esse trabalho silencioso preparou o terreno para as oficinas que se desenvolveriam no ano seguinte, e para uma primeira leitura pública no Festival de São José do Rio Preto, em julho de 2001. Num ano de muitas realizaçōes de José Celso - a remontagem de quatro das principais encenações do Oficina na década de 1990 para gravação em DVD, e a montagem de Esperando Godot, de Samuel Beckett, no Rio de Janeiro - o processo de gestação prosseguiu no trabalho diário do núcleo de atores criado nas oficinas. Finalmente, em 2002, a montagem do texto integral de Os Sertóes tornou-se o projeto prioritário do grupo e passou a concentrar todas as atenções do encenador. Enquanto o coletivo do Oficina, dirigido por Marcelo Drumonnd, realizava novas oficinas na periferia de São Paulo, José Celso e dois colaboradores, Tomy Pietra e Flávio Rocha, iniciaram mais uma leitura do livro, desta vez para descobrir a estrutura dramática implícita ao texto e traçar as bases da dramaturgia. Rolos de papel kraft foram rabiscados com lápis de cor, demarcando as células de ação e constituindo o que os membros do grupo chamam de "os cadernos de direção".

Para José Celso, a enésima leitura, desta vez com a preocupação objetiva de encenar o texto todo, revelou-se uma primeira leitura. Uma teatralidade latente na prosa elíptica de Euclídes foi sendo desvendada, percebida na 
coreografia das diversas missões militares que participaram do cerco a Canudos, nos gestos e movimento ágeis dos sertanejos, e até nas características dramáticas da vegetação e da paisagem da região de Canudos. É a riqueza desse processo criativo recente, alimentado por todos os processos anteriores e, agora, finalmente consumado numa dramaturgia e encenação de Os Sertôes, que este dossiê pretende recolher e apresentar.

O primeiro ensaio do dossiê é o de Maria Thereza Vargas, em que são descritos alguns dos momentos cruciais no encontro do Oficina com Os Sertôes e detalhada uma primeira encenação parcial, em 1989. Há, depois, uma entrevista com José Celso sobre o processo de transformação do livro em dramaturgia e as perspectivas da encenação, a essa altura já imaginada como sintetizando as três partes do livro e abdicando de uma versão integral. Segue-se um ensaio de Berthold Zilly, um dos tradutores de Os Sertôes para o alemão, sobre os aspectos espetaculares da obra de Euclides da Cunha. Completa o dossiê um artigo de Oswald de Andrade, publicado em 1943, no Diário de S. Paulo, sobre Os Sertôes, raríssimo achado de Catherine Hirsh, uma das colaboradoras mais importantes do Teatro Oficina hoje, numa biblioteca pública de São Paulo. Ao que tudo indica, o artigo, em que Oswald exalta a grandeza da obra de Euclides da Cunha e compara a contribuição do escritor com a oferecida por Gilberto Freyre, estava perdido e não integrava o catálogo de textos conhecidos do escritor. No texto, publicado na coluna Feira das Sextas, Oswald ressalta ainda, profeticamente, o exemplo da "rocha viva" de Canudos contra a dominação que, em plena segunda guerra mundial, percebia que os Estados Unidos exerceriam nos futuros tempos de paz.

$\mathrm{O}$ encarte central, com as imagens de todo este complexo processo de criação, reúne fotos, cenas de vídeo e uma variada iconografia que contempla os diversos processos em que o Oficina confrontou Os Sertôes, com destaque para os registros de ensaios, oficinas e apresentações parciais realizados nos últimos dois anos, e uma adaptação para quadrinhos do processo de 1989. Finalmente, integram o dossiê fragmentos da dramaturgia concretizada até setembro de 2002 e um mapa com as principais ocorrências de Os Sertôes na história do Oficina. 